\title{
Diyabetli Hastaların Ayak Bakımı ve Diyabetik Ayak Hakkındaki Bilgi, Tutum ve Davranışlarının Değerlendirilmesi
}

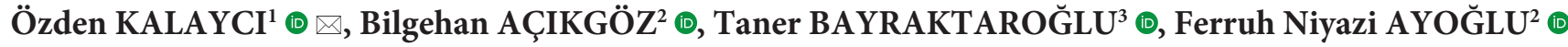 \\ 'Zonguldak Bülent Üniversitesi Sağllk Uygulama ve Araştırma Merkezi, Zonguldak, Türkiye \\ ${ }^{2}$ Zonguldak Bülent Ecevit Üniversitesi, Tip Fakültesi, Halk Sağlığı Anabilim Dalı, Zonguldak, Türkiye \\ ${ }^{3}$ Zonguldak Bülent Ecevit Üniversitesi, İç Hastalıkları Anabilim Dalı, Endokrinoloji ve Metabolizma Hastalıkları Bilim Dalı, Zonguldak, Türkiye
}

Bu makaleye yapılacak atıf: Kalaycı Ö, Açıkgöz B, Bayraktaroğlu T, Ayoğlu FN. Diyabetli Hastaların Ayak Bakımı ve Diyabetik Ayak Hakkındaki Bilgi, Tutum ve Davranışlarının Değerlendirilmesi. Türk Diyab Obez 2020;2: 98-107.

\section{ÖZ}

Amaç: $\mathrm{Bu}$ çalışmada, diyabetli hastaların ayak bakımı ve diyabetik ayak konusundaki bilgi, tutum ve davranışlarını saptamak ve hastalara yapılacak eğitim ihtiyacını ortaya koymak amaçlandı.

Gereç ve Yöntemler: Kesitsel tipte yapılan araştırmada 01.06.2015-31.08.2015 tarihleri arasında Zonguldak Bülent Ecevit Üniversitesi Endokrinoloji ve Metabolizma Hastalıkları Bilim Dalı Endokrinoloji polikliniği’ne başvuran ya da merkezin yataklı biriminde tedavi gören tüm diabetes mellitus tanılı hastalara ulaşılması planlanmıştır. Araştırma grubu hamile ya da engelli olmayan, 18 yaş üstü, çalışma hakkında bilgilendirilmiş ve çalışmaya katılmayı kabul etmiş 150 gönüllü diyabet hastasından oluşmaktadır. Hazırlanan anket formu yüz yüze görüşme tekniği ile uygulanmıştır ve veriler analiz edilmiştir.

Bulgular: Olguların \%50'si ayak bakımının önemli olduğunu düşünmektedirler. Olguların \%28,7'si her gün ayaklarını yıkadığı, \%21,3’ünün ayaklarını her gün kuruladığı ve \%77,3’ünün hiçbir zaman ayak bakım kremi kullanmadığı bulunmuştur. Ayrıca \%78,0’i ayakla ilgili bir sorun yaşadıklarında sağlık kuruluşuna başvurmaktadır. Ayak bakımı konusunda bilgi alan hastaların \%69,1'inin her gün ılık su ile ayaklarını yıkadığı, \%57,4’ünün ayaklarını kuruladığı bulunmuş olup ayak bakım davranışları bakımından (ayaklarını yıkama, ayaklarını kurulama, ayaklarına krem kullanma) bilgi alma durumlarına göre anlamlı fark bulunmuştur.

Sonuç: Araştırmamızın sonuçlarına göre diyabetin sık görülen komplikasyonlarından diyabetik ayak oluşma riskini azaltabilmek için hastalar bu anlamda takip edilmeli, değerlendirilmelidir. Olumlu davranış değişikliklerinin oluşturulabilmesi için eğiten, koruyucu hekimlik felsefesinin önemsendiği merkezlere ihtiyaç vardır.

Anahtar Sözcükler: Diabetes mellitus, Ayak bakımı, Diyabetik ayak

\section{Evaluation of Foot Care of Diabeted Patients and the Knowledge, Attitude and Behavior About Diabetic Foot}

\begin{abstract}
Aim: In this study, it was aimed to determine the knowledge, attitudes and behaviors of diabetic patients about foot care and diabetic foot and to reveal the need for training for patients.

Material and Methods: In the cross-sectional study, between 01.06.2015-31.08.2015, B.E.Ü. It is planned to reach all the patients diagnosed with diabetes mellitus who applied to the Endocrinology Outpatient Clinic of Health Application and Research Center or treated in the inpatient unit of the center. The study group consisted of 150 volunteer diabetic patients who were pregnant or nondisabled, over the age of 18, informed about the study and agreed to participate in the study. The questionnaire form was applied by face to face interview technique and the data were analyzed.

Results: $50 \%$ of the patients think that foot care is important. It was found that $28.7 \%$ of the patients washed their feet every day, $21.3 \%$ of them dry their feet every day and $77.3 \%$ never used foot care cream. In addition, $78.0 \%$ of them apply to the health institution when


they have a foot problem. It was found that $69.1 \%$ of the patients who received information about foot care were washing their feet with warm water every day, $57.4 \%$ of them were drying their feet.

Conclusion: According to the results of our study, patients should be followed and evaluated in this sense in order to reduce the risk of developing diabetic foot which is one of the common complications of diabetes. $\mathrm{n}$ order to create positive behavioral changes, there is a need for centers where educators and preventive medicine philosophy are considered.

Key Words: Diabetes mellitus, Foot care, Diabetic foot

\section{GİRIŞ}

Diyabet, insülin eksikliği ya da insülin etkisindeki defektler nedeniyle organizmanın karbonhidrat $(\mathrm{KH})$, yağ ve proteinlerden yeterince yararlanamadığı, sürekli tıbbi bakım gerektiren, kronik bir metabolizma hastalığıdır (1). Dünyadaki prevelansı 2011 yılı itibari ile 366 milyon olup bu sayı her yıl giderek artmaktadır. Bu sayının 2030 yılında 552 milyon olacağı tahmin edilmektedir (2). Bunun başlıca nedenleri nüfus artışı, yaşlanma ve kentleşmenin getirdiği yaşam tarzı değişimi sonucu obezite ve fiziksel inaktivitenin artmasıdır (3). Diyabetik hastaların hastaneye yatışlarının en sık nedenleri, kan şeker regülasyonu takibi, diyabetik ketoasidoz komaları, böbrek yetmezliği, retinopatiler ve ayak sorunları olarak sıralanmaktadır. DM kendisinin vücutta yaptığı kan şeker/ insülin irregülasyonu yanı sıra uzun dönemli periferik nöropati (PN) ve periferik vasküler hastalık (PVH) sonucu gelişen periferik organ ve ekstremite tutulumu komplikasyonları önemli morbidite ve mortalite nedenidir (2). Pek çok ülkede yapılan çalışmalar, diyabetin yalnızca sağlıklı yaşam tarzı değişiklikleri ile \%44-58 oranında risk azalması sağlanarak önlenebileceğini veya en kötümser tahminle geciktirilebileceğini göstermiştir $(4,5)$.

Diyabetiklerin hastaneye yatı̧s nedenlerinin yaklaşı \%50'si kronik komplikasyonlardır ve bu durum yüksek tedavi maliyetleri ve artmış iş gücü kaybıyla sonuçlanmaktadır. Diyabetik hastaların yaşam süre ve kalitesini belirleyen faktörlerden biri olan diyabetik ayak ülserleri, diyabetik hastaların en sık hastaneye yatış ve cerrahi müdahale sebeplerindendir. Diyabetik ayak, diyabette morbiditeyi etkileyen, tedavisi pahalı olan, sadece hasta eğitimi ile önlenebilen önemli bir komplikasyondur (6). Geliştirilen modern tedavi yöntemleri, eğitim programları ve ayaklara yönelik bakım ürünlerine rağmen diyabetik hastaların \%25’i hayatlarının bir döneminde alt ekstremite enfeksiyonu geçirmektedir (7). Diyabetik ayak komplikasyonları, gelişmiş toplumlarda travma dışı alt ekstremite ampütasyon nedenleri arasında yaygındır (7). Amputasyon gerekliliğinin en önemli nedeni diyabetik ayak enfeksiyonları iken, diyabetik hastaların \% 1 'inde de ampütasyon gerekir. Bu oran genel popülasyondakinden 15 kat daha fazladır (6). Bu nedenle diyabetiklerde ayak bakımı çok önemlidir ve bu konuya yönelik hasta eğiti- mine diyabet tanısı konulduktan hemen sonra başlanmalıdır. Diyabetli hastaların ayak bakımı konusunda eğitilmesi alt ekstremite problemlerinin önlenmesinde önemli rol oynar. Risk altında olan bireylerin erken tanınması ve tanı konulduktan sonra da yaşam boyu eğitiminin sürdürülmesi oldukça önemlidir. Eğitim ile diyabetli hastalarda görülen komplikasyonlar azalacağı gibi yaşam kalitesi de artacaktır (8).

$\mathrm{Bu}$ çalışma, diyabetli hastaların ayak bakımı ve diyabetik ayak konusundaki bilgi, tutum ve davranışlarını saptamak ve hastalara yapılacak eğitim ihtiyacını ortaya koymak amacı ile planlanmıştır (6).

\section{GEREÇ ve YÖNTEMLER}

Araştırma, Zonguldak Bülent Ecevit Üniversitesi Tip Fakültesi Klinik Araştırmalar Etik Kurulu'ndan alınan etik kurul iznini takiben başlatılmıştır. Bu kesitsel araştırma 01.06.2015-31.08.2015 tarihleri arasında Zonguldak Bülent Ecevit Üniversitesi Endokrinoloji ve Metabolizma Hastalıkları Bilim Dalı Endokrinoloji polikliniği'ne başvuran ya da merkezin yataklı biriminde tedavi gören tüm hastalara ulaşılması planlanarak yapılmıştır. Araştırma grubu hamile ya da engelli olmayan, 18 yaş üstü, çalışma hakkında bilgilendirilmiş ve çalışmaya katılmayı kabul etmiş 150 gönüllü diyabet hastasından oluşturulmuştur. Araştırmacılar tarafindan literatür incelenerek hazırlanan anket formu yüz yüze görüşme tekniği ile uygulanmıştır. Araştırmacıların sosyo-demografik özelliklere ilişkin değişkenleri (yaş, cinsiyet, medeni durum, öğrenim durumu, aylık hane geliri), alışkanlıklarla ilgili değişkenleri (sigara-tütün kullanımı, egzersiz durumlarına uyum düzeni, diyetlerine uyum düzeni, tedaviye uyum, ayak bakımı alışkanlıkları), hastalık durumlarına ilişkin değişkenleri (kaç yıldır DM hastası olduğu, akrabalarında DM tanısı almış olanların varlığı, hastalığa yönelik almış oldukları tedavi biçimleri, kontrol sıklıkları, hastalığa yönelik ek bir sorun yaşama durumları, hekim tarafından tanı konan başka bir kronik hastalığının bulunma durumu) ve bilgi, tutum ve davranış ile ilgili değişkenler (ayak bakımının önemi hakkındaki düşünceleri, ayak bakımı konusunda bilgi alma durumları ve bilgi kaynakları, ayak bakım ile ilgili bilgi, tutum ve davranışları) kaydedilmiştir. 
Bilgi, tutum ve davranış ile ilgili değişkenlere ait tanım ve ölçütler;

- Kişiye diyabet hastalığında ayak bakımının öneminin olup olmadığı beşli likert soru şeklinde,

- Daha önce ayak bakımı konusunda bilgi alma durumu evet / hayır seçenekleriyle ve

- Bilgi aldıkları kaynaklar da; sağlık personeli (doktor, hemşire), çevre (arkadaş, akraba), dergi, gazete vb., televizyon (sağlıkla ilgili programlar vs.), diğerleri şeklinde soruldu,

- Diyet, egzersiz ve tedaviye uyum şekli,

- Ayaklarını her gün ılık sabunlu su ile yıkama, kurulama, ayak bakımı için özel kremler kullanma, ayaklarını her yıkamadan sonra muayene etme, evde yürürken terlik giymeye özen gösterme, ayakkabılarını giymeden önce ayakkabının içini kontrol etme tutum ve davranışları, tırnak kesme biçimleri, giymeyi tercih ettikleri çorap ve ayakkabı türü ile ilgili bilgi, tutum ve davranışları beşli likert soru biçiminde,

- Ayaklarıyla ilgili bir sorun yaşadıklarında ne gibi uygulamalarda bulundukları; sağlık kurumuna başvururum (sağlık ocağı, hastaneler, özel klinikler vs.), kendi kendime antibiyotik kullanırım, her gün sabunlu su ile yıkar ve ayağımı kurularım, geleneksel ilaçlar kullanırım ve önemsemem seçenekleriyle sorulmuştur.

\section{İstatistiksel Analiz}

Veriler SPSS 19.0 programı kullanılarak bilgisayara aktarıldı. Tanımlayıcı bulgular sayı, yüzde, ortalama \pm standart sapma şeklinde sunuldu. Gruplar arası karşılaştırmalarda kategorik verilerin karşılaştırılmasında ki-kare testi kullanıldı. Sonuçlar \%95 güven aralığında değerlendirildi. Anlamlılık sınırı olarak $\mathrm{p}<0.05$ değerleri kabul edildi.

\section{BULGULAR}

Çalışmaya katılan 150 diyabet olgusunun 92'sini $(\% 61,3)$ kadınlar, 58'ini $(\% 38,7)$ erkekler oluşturmuştur. Olguların 91'i $(\% 60,7)$ ilkokul mezunudur. 133'ü $(\% 88,7)$ evli, 88'i $(\% 58,7)$ ev kadınıdır ve 147 'sinin $(\% 98,0)$ sağlık güvencesi olduğu saptanmıştır (Tablo 1).

Çalışmaya katılan olguların Diyabet süresi 1 yıl ile 30 yıl arasinda olup ortalama 9,4 yıldır $(9,4 \pm 6,9)$. Olguların 29 'u (\%19,3) sigara kullanmakta, 113'ünde $(\% 75,3)$ ek bir kronik hastalık bulunmaktadır. Ayrıca olguların 99'unun (\%66) akrabasında Diyabet tanısı vardır. Olguların sadece 1'i $(\% 0,7)$ tedavi şekli olarak tedavinin ilk basamağ olan diyet-egzersiz uygularken, 62'si $(\% 41,3)$ insülin, 46’s1 $(\% 30,7)$ oral antidiyabetik (OAD) ve 41 'i $(\% 27,3)$ insülin+OAD kullanmaktadır (Tablo 2).
Tablo 1: Katılımcıların sosyodemografik özellikleri.

\begin{tabular}{|c|c|c|}
\hline \multicolumn{2}{|c|}{ Sosyodemografik özellikler } & \multirow{2}{*}{$\begin{array}{c}\begin{array}{c}\text { Olgu Sayısı } \\
\text { n (\%) }\end{array} \\
92(61,3) \\
\end{array}$} \\
\hline Cinciyet & Kadın & \\
\hline Cinsiyet & Erkek & $58(38,7)$ \\
\hline \multirow{5}{*}{$\begin{array}{l}\text { Eğitim } \\
\text { durumları }\end{array}$} & Okur-yazar değil & $24(16,0)$ \\
\hline & İlkokul & $91(60,7)$ \\
\hline & Ortaokul & $17(11,3)$ \\
\hline & Lise & $14(9,3)$ \\
\hline & Üniversite- yüksek lisans & $4(2,7)$ \\
\hline \multirow{2}{*}{$\begin{array}{l}\text { Medeni } \\
\text { durum }\end{array}$} & Evli & $133(88,7)$ \\
\hline & Bekâr & $17(11,3)$ \\
\hline \multirow{5}{*}{ Meslek } & Memur & $2(1,3)$ \\
\hline & İşçi & $7(4,7)$ \\
\hline & Serbest meslek & $15(10,0)$ \\
\hline & Emekli & $38(25,3)$ \\
\hline & Ev kadını & $88(58,7)$ \\
\hline \multirow{2}{*}{$\begin{array}{l}\text { Sosyal } \\
\text { güvence }\end{array}$} & Var & $147(98,0)$ \\
\hline & Yok & $3(2,0)$ \\
\hline
\end{tabular}

Tablo 2: Katılımcıların aldıkları tedavi şekline göre dağılım tablosu.

\begin{tabular}{lc}
\hline Tedavi şekli & $\begin{array}{c}\text { Olgu Sayısı } \\
\text { n (\%) }\end{array}$ \\
\hline Egzersiz-diyet & $1(0,7)$ \\
\hline Oral antidiyabetik (OAD) & $46(30,7)$ \\
\hline İnsülin & $62(41,3)$ \\
\hline İnsülin+OAD & $41(27,3)$ \\
\hline Toplam & $150(100,0)$ \\
\hline
\end{tabular}

Araştırmaya katılan gönüllülerin 42 'sinde $(\% 28,0)$ diyabetik nöropati bulunurken, 23'ünde (\%15,3) diyabetik nefropati, 20 'sinde $(\% 13,3)$ diyabetik retinopati, 15 'inde $(\% 10,0)$ diyabetik kardiyovasküler hastalık vardır ve 143 'ü $(\% 95,3)$ diyabetik koma yaşamıştır. Olguların diyabetik komplikasyon yaşama durumları Tablo 3 'te gösterilmiştir. Ayrıca olguların 52'si $(\% 34,7)$ yılda 4 kez kontrole gitmektedir.

Olguların 75’i (\%50) diyabet hastalığında ayak bakımının kesinlikle önemli olduğunu düşünmekte iken, 12'si $(\% 8,0)$ kesinlikle önemli olmadığını düşünmektedir. Olguların ayak bakımının önemi hakkındaki düşünceleri Tablo 4'te gösterilmiştir.

Araştırmaya katılan olguların 43'ünün $(\% 28,7)$ her gün düzenli olarak ayaklarını yıkadığı, 5 'inin $(\% 3,3)$ ise nadiren yıkadığı, 32'sinin $(\% 21,3)$ her gün ayaklarını kuruladığı ve 
56 ’sının $(\% 37,3)$ hiç kurulamadığı, 4'ünün $(\% 2,7)$ her gün düzenli olarak ayak bakım kremi kullandığ 1 ve 116 'sının $(\% 77,3)$ hiç kullanmadığı ve yine gönüllülerin 25 'inin $(\% 16,7)$ ayaklarını muayene ettiği ve $46^{\prime} \operatorname{s} ı n ı n ~(\% 30,7)$ hiç muayene etmediği bulunmuştur. Olguların ayak yıkama, ayak kurulama, ayak bakım kremi kullanma ve ayak muayenesi konusundaki davranışları Tablo 5'te gösterilmiştir.

Olguların 47’sinin $(\% 31,3)$ tırnaklarını düz bir şekilde kestiği, 58'inin $(\% 38,7)$ yuvarlak-oval şekilde kestiği bulunmuştur. Olguların 85'inin (\%56,7) pamuklu çorap kullan-

Tablo 3: Olguların diyabetik komplikasyon yaşama durumlarına göre dağılımlarının tablosu.

\begin{tabular}{llc}
\hline Komplikasyonlar & & $\begin{array}{c}\text { Olgu Sayısı } \\
\text { n (\%) }\end{array}$ \\
\hline Diyabetik nöropati & Var & $42(28,0)$ \\
\cline { 2 - 3 } Diyabetik nöropati & Yok & $108(72,0)$ \\
\cline { 2 - 3 } Var & Yok & $127(15,2)$ \\
\hline Diyabetik retinopati & Var & $20(13,3)$ \\
\cline { 2 - 3 } $\begin{array}{l}\text { Diyabetik kardiyovasküler } \\
\text { komplikasyonlar }\end{array}$ & Var & $130(86,7)$ \\
\cline { 2 - 3 } Diyabetik koma & Yok & $13(10,0)$ \\
\hline
\end{tabular}

Tablo 4: Olguların ayak bakımının önemi hakkındaki düşünceleri.

\begin{tabular}{lc}
\hline Ayak bakımının önemi & $\begin{array}{c}\text { Olgu Sayısı } \\
\mathbf{n}(\%)\end{array}$ \\
\hline Kesinlikle var & $75(50,0)$ \\
\hline Kısmen var & $31(20,7)$ \\
\hline Fikrim yok & $24(16,0)$ \\
\hline Kısmen yok & $8(5,3)$ \\
\hline Kesinlikle yok & $12(8,0)$ \\
\hline Toplam & $150(100)$ \\
\hline
\end{tabular}

dığ 1 , 2'sinin ise $(\% 1,3)$ yün çorap kullanmakta olduğu bulunmuştur. Olguların 114 'ünün $(\% 76,0)$ topuksuz ayakkabı giymeyi tercih ederken, 4 'ü $(\% 2,7)$ çok topuklu ayakkabı kullanmaktadır. Olguların 7'sinin $(\% 4,7)$ evde terlik giymeye nadiren dikkat ettiği ve $89^{\prime}$ unun $(\% 59,3)$ hiç dikkat etmediği bulunmuştur. Olguların 24'ünün (\%16) her zaman düzenli olarak ayakkabılarını giymeden önce içini kontrol ettiği, 83'ünün $(\% 55,3)$ hiçbir zaman kontrol etmediği bulunmuştur. Olguların tırnak kesme biçimleri, kullandıkları çorap ve ayakkabı türleri, evde terlik giyme durumları, ayakkabılarını giymeden önce kontrol etme durumları Tablo 6'da gösterilmiştir.

Olguların 69'unun $(\% 46,0)$ genellikle bir ayak enfeksiyonu yaşadığı, 55'inin $(\% 36,7)$ hiç ayakta nasırlaşma durumu yaşamadığı 119 'unun $(\% 79,3)$ ayağında hiç bül oluşmadığı, 55 'inin $(\% 36,7)$ genellikle ayakta çatlak-kuruluk durumu yaşadığ 1,141 'inin $(\% 94,0)$ hiç ayakta ülser durumu yaşamadığı, 73'ünün $(\% 48,7)$ her zaman ayakta yanma hissi yaşadığ 1,47 'sinin $(\% 31,3)$ bazen ayakta karıncalanma hissi yaşadığ 1,49 'unun $(\% 32,7)$ hiç ayakta soğukluk hissi yaşamadığı yine 118 'inin $(\% 78,7)$ ise hiç ayakta his kaybı yaşamadığı bulunmuştur. Olguların ayakta enfeksiyon, nasırlaşma, bül, çatlak-kuruluk, ülserleşme, yanma, karıncalanma, soğukluk ve his kaybı yaşama durumları Tablo 7'de gösterilmiştir.

Olguların ayak bakımı konusunda bilgi alma durumlarına göre ayak bakımının önemli olduğunu düşünme sıklıkları arasında anlamlı bir fark olduğu görülmüștür. Ayak bakımı konusunda bilgi alan Olguların \%94,1'inin ayak bakımının önemli olduğunu, bilgi almayanların \% 8,80'inin hiç önemli olmadığını düşündüğü görülmüştür. Yine olguların bilgi alma durumlarına göre ayakların her gün ılık su ile yıkanması, kurulanması, ayak bakımı için krem kullanma durumları değişmektedir. Bilgi alan olgularda ayaklarını yıkama, kurulama ve ayak bakımı için krem kullanması davranışlarının yüksek olduğu görülmüştür. Ayak bakımı konusunda bilgi alan olguların \%69,1'inin ayaklarını her gün ılık su ile yıkadığı, \%57,4'ünün ayak kurulamaya çok özen gösterdiği, $\% 10,3$ 'ünün ayak bakımı için çoğunlukla krem kullandığ 1 görülmüştür.

Tablo 5: Olguların ayak yıkama, ayak kurulama, ayak bakım kremi kullanma ve ayak muayenesi konusundaki davranışları.

\begin{tabular}{lccccc}
\hline & $\begin{array}{c}\text { Her gün } \\
\text { yaparım n (\%) }\end{array}$ & $\begin{array}{c}\text { Genellikle } \\
\text { yaparım n (\%) }\end{array}$ & $\begin{array}{c}\text { Ara sıra } \\
\text { yaparım n (\%) }\end{array}$ & $\begin{array}{c}\text { Nadiren } \\
\text { yaparım n (\%) }\end{array}$ & $\begin{array}{c}\text { Hiç yapmam } \\
\text { n (\%) }\end{array}$ \\
\hline Ayak yıkama & $43(28,7)$ & $42(28,0)$ & $30(20,0)$ & $5(3,3)$ & $30(20,0)$ \\
\hline Ayak kurulama & $32(21,3)$ & $31(20,7)$ & $22(14,7)$ & $9(6,0)$ & $56(37,3)$ \\
\hline Ayak bakım kremi kullanma & $4(2,7)$ & $5(3,3)$ & $14(9,3)$ & $11(7,3)$ & $116(77,3)$ \\
\hline Ayak muayene etme & $25(16,7)$ & $36(24)$ & $30(20)$ & $13(8,7)$ & $46(30,7)$ \\
\hline
\end{tabular}


Olguların ayak bakımıyla ilgili bilgi alma durumlarına göre ayak bakımı davranışları Tablo 8'de gösterilmiştir.

Olguların eğitim durumlarına göre çatlak-kuruluk, ülserasyon ve soğukluk yaşama durumu anlamlı farklılık göster- mektedir. Okur-yazar olmayan olguların \%79,2'sinin ayaklarıyla ilgili çatlak-kuruluk durumu yaşarken, üniversite/ yüksek lisans mezunu hastaların \%75,0'inin ayaklarıyla ilgili çatlak-kuruluk durumu çok az yaşadığı ya da hiç yaşamadığı,

Tablo 6: Olguların tırnak kesme biçimleri, kullandıkları çorap ve ayakkabı türleri, evde terlik giyme durumları, ayakkabılarını giymeden önce kontrol etme durumları.

\begin{tabular}{|c|c|c|}
\hline \multicolumn{2}{|c|}{ Tirnak, Çorap, Terlik ve Ayakkabı Giyim Kontrol Durumları } & \multirow{2}{*}{$\begin{array}{c}\begin{array}{c}\text { Olgu Sayısı } \\
\text { n (\%) }\end{array} \\
47(31,3) \\
\end{array}$} \\
\hline \multirow{3}{*}{ Tirnak kesme biçimleri } & Düz & \\
\hline & Yuvarlak-oval & $58(38,7)$ \\
\hline & Gelişi güzel & $45(30,0)$ \\
\hline \multirow{4}{*}{ Kullandıkları çorap türü } & Sentetik & $15(10,0)$ \\
\hline & Pamuklu & $85(56,7)$ \\
\hline & Yün & $2(1,3)$ \\
\hline & Karışık & $48(32,0)$ \\
\hline \multirow{4}{*}{ Kullandıkları ayakkabı türü } & Topuksuz -düz & $114(76,0)$ \\
\hline & Az topuklu & $21(14,0)$ \\
\hline & Çok topuklu & $4(2,7)$ \\
\hline & Ortopedik taban & $11(7,3)$ \\
\hline \multirow{5}{*}{ Evde terlik kullanma durumları } & Her gün & $24(16,0)$ \\
\hline & Genellikle & $16(10,7)$ \\
\hline & Bazen & $14(9,3)$ \\
\hline & Nadiren & $7(4,7)$ \\
\hline & Hiç dikkat etmem & $89(59,3)$ \\
\hline \multirow{5}{*}{ Ayakkabı kontrolü } & Her zaman ederim & $24(16,0)$ \\
\hline & Genellikle ederim & $20(13,3)$ \\
\hline & Bazen ederim & $17(11,3)$ \\
\hline & Nadiren ederim & $6(4,0)$ \\
\hline & Hiçbir zaman kontrol etmem & $83(55,3)$ \\
\hline
\end{tabular}

Tablo 7: Olguların ayakta enfeksiyon, nasırlaşma, bül, çatlak-kuruluk, ülserleşme, yanma, karıncalanma, soğukluk ve his kaybı yaşama durumları.

\begin{tabular}{|c|c|c|c|c|c|}
\hline & $\begin{array}{c}\text { Her zaman } \\
\text { yaşarım n (\%) }\end{array}$ & $\begin{array}{c}\text { Genellikle } \\
\text { yaşarım n (\%) }\end{array}$ & $\begin{array}{c}\text { Bazen yaşarım } \\
\text { n (\%) }\end{array}$ & $\begin{array}{c}\text { Nadiren } \\
\text { yaşarım n } \mathbf{n}(\%)\end{array}$ & $\begin{array}{c}\text { Hiç yaşamadım } \\
\text { n (\%) }\end{array}$ \\
\hline Ayak enfeksiyonu & $22(14,7)$ & $69(46,0)$ & $31(20,7)$ & $6(4,0)$ & $22(14,7)$ \\
\hline Nasırlaşma & $25(16,7)$ & $39(26,0)$ & $27(18,0)$ & $4(2,7)$ & $55(36,7)$ \\
\hline Bül & $0(0,0)$ & $4(2,7)$ & $6(4,0)$ & $21(14)$ & $119(79,3)$ \\
\hline Çatlak-kuruluk & $54(36,0)$ & $55(36,7)$ & $20(13,3)$ & $3(2,0)$ & $18(12,0)$ \\
\hline Ülser & $2(1,3)$ & $2(1,3)$ & $4(2,7)$ & $1(0,7)$ & $141(94,0)$ \\
\hline Yanma & $73(48,7)$ & $28(18,7)$ & $35(23,3)$ & $3(2,0)$ & $11(7,3)$ \\
\hline Karıncalanma & $44(29,3)$ & $30(20,0)$ & $47(31,3)$ & $4(2,7)$ & $25(16,7)$ \\
\hline Soğukluk & $32(21,3)$ & $18(12,0)$ & $44(29,3)$ & $7(4,7)$ & $49(32,7)$ \\
\hline His kaybı & $8(5,3)$ & $7(4,7)$ & $10(6,7)$ & $7(4,7)$ & $118(78,7)$ \\
\hline
\end{tabular}


Tablo 8: Olguların ayak bakımıyla ilgili bilgi alma durumlarına göre ayak bakımı davranışları ile ayak ile ilgili komplikasyon yaşama durumları.

\begin{tabular}{|c|c|c|c|}
\hline & $\begin{array}{c}\text { Ayak bakımı } \\
\text { konusunda bilgi } \\
\text { alanlar n (\%) }\end{array}$ & $\begin{array}{c}\text { Ayak bakımı } \\
\text { konusunda bilgi } \\
\text { almayanlar } \mathbf{n}(\%)\end{array}$ & $\mathbf{P}$ \\
\hline $\begin{array}{l}\text { Ayak bakımının sıklıkla önemli } \\
\text { olduğunu düşünenler }\end{array}$ & $64(94,1)$ & $42(51,2)$ & \multirow{2}{*}{0,001} \\
\hline $\begin{array}{l}\text { Ayak bakımının çok az önemli olduğunu ya da } \\
\text { hiç önemli olmadığını düşünenler }\end{array}$ & $4(5,9)$ & $40(48,8)$ & \\
\hline $\begin{array}{l}\text { Ayaklarını sıklıkla ılık su ile } \\
\text { yıkayanlar }\end{array}$ & $47(69,1)$ & $38(46,3)$ & \multirow{2}{*}{0,005} \\
\hline $\begin{array}{l}\text { Ayaklarını nadiren yıkayanlar ya da } \\
\text { hiç yıkamayanlar }\end{array}$ & $21(30,9)$ & $44(53,7)$ & \\
\hline $\begin{array}{l}\text { Ayaklarını sıklıkla } \\
\text { kurulayanlar }\end{array}$ & $39(57,4)$ & $24(29,3)$ & \multirow{2}{*}{0,001} \\
\hline $\begin{array}{l}\text { Ayaklarını nadiren kurulayanlar ya da } \\
\text { hiç kurulamayanlar }\end{array}$ & $29(42,6)$ & $58(70,7)$ & \\
\hline $\begin{array}{l}\text { Siklıkla ayak bakım kremi } \\
\text { kullananlar }\end{array}$ & $7(10,3)$ & $2(2,4)$ & \multirow{2}{*}{0,044} \\
\hline $\begin{array}{l}\text { Ayak bakımı için nadiren krem kullananlar ya da } \\
\text { hiç kullanmayanlar }\end{array}$ & $61(89,7)$ & $80(97,6)$ & \\
\hline $\begin{array}{l}\text { Ayak muayenesini sıklıkla } \\
\text { yapanlar }\end{array}$ & $32(47,1)$ & $29(35,4)$ & \multirow{2}{*}{0,147} \\
\hline $\begin{array}{l}\text { Ayak muayenesini nadiren yapanlar ya da } \\
\text { hiç yapmayanlar }\end{array}$ & $36(52,9)$ & $53(64,6)$ & \\
\hline $\begin{array}{l}\text { Siklıkla evde terlik } \\
\text { kullananlar }\end{array}$ & $22(32,4)$ & $18(22,0)$ & \multirow{2}{*}{0,152} \\
\hline $\begin{array}{l}\text { Evde nadiren terlik kullananlar ya da } \\
\text { hiç kullanmayanlar }\end{array}$ & $46(67,6)$ & $64(78,0)$ & \\
\hline $\begin{array}{l}\text { Ayakkabılarını giymeden önce ayakkabının içini } \\
\text { sıklıkla kontrol edenler }\end{array}$ & $18(26,5)$ & $26(31,7)$ & \multirow{2}{*}{0,483} \\
\hline $\begin{array}{l}\text { Ayakkabılarını giymeden önce ayakkabılarının içini } \\
\text { nadiren kontrol edenler ya da hiç kontrol etmeyenler }\end{array}$ & $50(73,5)$ & $56(68,3)$ & \\
\hline
\end{tabular}

ortaokul mezunu olguların \%17,6’sı ayaklarıyla ilgili ülserasyon durumu yaşarken, üniversite/yüksek lisans mezunu olguların \%100,0’ünün ülserasyon sorununu çok az yaşadığı ya da hiç yaşamadığı, yine okur-yazar olmayan hastaların $\% 45,8$ 'inin ayaklarıyla ilgili soğukluk durumu yaşadığı, üniversite/yüksek lisans mezunu olanların \%100,0’ünün soğukluk sorununu çok az yaşadığı ya da hiç yaşamadığ 1 bulunmuştur.

Olguların eğitim durumlarına göre komplikasyon yaşama durumları Tablo 9'da gösterilmiştir.

\section{TARTIŞMA}

Çalışmamızda hastaların sadece biri $(\% 0,7)$ tedavi şekli olarak tedavinin ilk basamağ 1 olan diyet-egzersiz uygularken, 62'si $(\% 41,3)$ insülin kullanmaktadır. Sürmeli'nin Kayseri'de 30 diyabetli hastanın kişisel özellikleri ve tedavi sonuçlarını değerlendirmek için yapmış olduğu araştırmasında hastaların \%43,33'ü tedavi şekli olarak insülin kullanmaktadır (9). Yine bu çalışma bizim çalışmamızla benzerlik göstermektedir. Hastaların çoğunluğu diyabette tedavinin son basamağı olan insülin tedavisi almaktadır. Ayrıca çalış- 
Tablo 9: Olguların eğitim durumlarına göre ayak bakımının önemi hakkındaki düşünce, ayak bakımı davranışları ve ayaklarıyla ilgili komplikasyon yaşama durumları.

\begin{tabular}{|c|c|c|c|c|c|c|}
\hline & $\begin{array}{l}\text { Okur yazar } \\
\text { değil }\end{array}$ & $\begin{array}{l}\text { İlkokul } \\
\text { mezunu }\end{array}$ & $\begin{array}{c}\text { Ortaokul } \\
\text { mezunu }\end{array}$ & $\begin{array}{c}\text { Lise } \\
\text { mezunu }\end{array}$ & $\begin{array}{l}\text { Üniversite } \\
\text { yükseklisans }\end{array}$ & $\mathbf{P}$ \\
\hline Sıklıkla bül oluşumu yaşayanlar & $\begin{array}{c}1 \\
(4,2) \\
\end{array}$ & $\begin{array}{c}2 \\
(2,2) \\
\end{array}$ & $\begin{array}{c}0 \\
(0,0) \\
\end{array}$ & $\begin{array}{c}1 \\
(7,1) \\
\end{array}$ & $\begin{array}{c}0 \\
(0,0) \\
\end{array}$ & \multirow{2}{*}{0,747} \\
\hline $\begin{array}{l}\text { Nadiren bül sorunu yaşayanlar ya da } \\
\text { hiç yaşamayanlar }\end{array}$ & $\begin{array}{c}23 \\
(95,8)\end{array}$ & $\begin{array}{c}89 \\
(97,8)\end{array}$ & $\begin{array}{c}17 \\
(100,0)\end{array}$ & $\begin{array}{c}13 \\
(92,9) \\
\end{array}$ & $\begin{array}{c}4 \\
(100,0) \\
\end{array}$ & \\
\hline Sıklıkla çatlak-kuruluk sorunu yaşayanlar & $\begin{array}{c}19 \\
(79,2)\end{array}$ & $\begin{array}{c}62 \\
(68,1)\end{array}$ & $\begin{array}{c}14 \\
(82,4)\end{array}$ & $\begin{array}{c}13 \\
(92,9)\end{array}$ & $\begin{array}{c}1 \\
(25,0)\end{array}$ & \multirow{2}{*}{0,046} \\
\hline $\begin{array}{l}\text { Nadiren çatlak-kuruluk sorunu yaşayanlar } \\
\text { ya da hiç yaşamayanlar }\end{array}$ & $\begin{array}{c}5 \\
(20,8) \\
\end{array}$ & $\begin{array}{c}29 \\
(31,9)\end{array}$ & $\begin{array}{c}3 \\
(17,6)\end{array}$ & $\begin{array}{c}1 \\
(7,1)\end{array}$ & $\begin{array}{c}3 \\
(75,0) \\
\end{array}$ & \\
\hline Sıklıkla ülserasyon sorunu yaşayanlar & $\begin{array}{c}0 \\
(0,0) \\
\end{array}$ & $\begin{array}{c}1 \\
(1,1)\end{array}$ & $\begin{array}{c}3 \\
(17,6)\end{array}$ & $\begin{array}{c}0 \\
(0,0)\end{array}$ & $\begin{array}{c}0 \\
(0,0)\end{array}$ & \multirow{2}{*}{0,002} \\
\hline $\begin{array}{l}\text { Nadiren ülserasyon sorunu yaşayanlar ya da } \\
\text { hiç yaşamayanlar }\end{array}$ & $\begin{array}{c}24 \\
(100,0) \\
\end{array}$ & $\begin{array}{c}90 \\
(98,9)\end{array}$ & $\begin{array}{c}14 \\
(82,4)\end{array}$ & $\begin{array}{c}14 \\
(100,0) \\
\end{array}$ & $\begin{array}{c}4 \\
(100,0) \\
\end{array}$ & \\
\hline Sıklıkla yanma sorunu yaşayanlar & $\begin{array}{c}20 \\
(83,3)\end{array}$ & $\begin{array}{c}59 \\
(64,8)\end{array}$ & $\begin{array}{c}13 \\
(76,5)\end{array}$ & $\begin{array}{c}6 \\
(42,9) \\
\end{array}$ & $\begin{array}{c}3 \\
(75,0) \\
\end{array}$ & \multirow{2}{*}{0,107} \\
\hline $\begin{array}{l}\text { Nadiren yanma sorunu yaşayanlar ya da } \\
\text { hiç yaşamayanlar }\end{array}$ & $\begin{array}{c}4 \\
(16,7) \\
\end{array}$ & $\begin{array}{c}32 \\
(35,2) \\
\end{array}$ & $\begin{array}{c}4 \\
(23,5) \\
\end{array}$ & $\begin{array}{c}8 \\
(57,1) \\
\end{array}$ & $\begin{array}{c}1 \\
(25,0) \\
\end{array}$ & \\
\hline Sıklıkla karıncalanma durumu yaşayanlar & $\begin{array}{c}15 \\
(62,5)\end{array}$ & $\begin{array}{c}43 \\
(47,3)\end{array}$ & $\begin{array}{c}9 \\
(52,9)\end{array}$ & $\begin{array}{c}6 \\
(42,9)\end{array}$ & $\begin{array}{c}1 \\
(25,0)\end{array}$ & \multirow{2}{*}{0,542} \\
\hline $\begin{array}{l}\text { Nadiren karıncalanma durumu yaşayanlar } \\
\text { ya da hiç yaşamayanlar }\end{array}$ & $\begin{array}{c}9 \\
(37,5)\end{array}$ & $\begin{array}{c}48 \\
(52,7) \\
\end{array}$ & $\begin{array}{c}8 \\
(47,1) \\
\end{array}$ & $\begin{array}{c}8 \\
(57,1) \\
\end{array}$ & $\begin{array}{c}3 \\
(75,0) \\
\end{array}$ & \\
\hline Sıklıkla soğukluk durumu yaşayanlar & $\begin{array}{c}11 \\
(45,8) \\
\end{array}$ & $\begin{array}{c}31 \\
(34,1) \\
\end{array}$ & $\begin{array}{c}8 \\
(47,1) \\
\end{array}$ & $\begin{array}{c}0 \\
(0,0) \\
\end{array}$ & $\begin{array}{c}0 \\
(0,0) \\
\end{array}$ & \multirow{2}{*}{0,016} \\
\hline $\begin{array}{l}\text { Nadiren soğukluk durumu yaşayanlar ya da } \\
\text { hiç yaşamayanlar }\end{array}$ & $\begin{array}{c}13 \\
(54,2)\end{array}$ & $\begin{array}{c}60 \\
(65,9) \\
\end{array}$ & $\begin{array}{c}9 \\
(52,9) \\
\end{array}$ & $\begin{array}{c}14 \\
(100,0) \\
\end{array}$ & $\begin{array}{c}4 \\
(100,0) \\
\end{array}$ & \\
\hline Sıklıkla his kaybı durumu yaşayanlar & $\begin{array}{c}3 \\
(12,5)\end{array}$ & $\begin{array}{c}8 \\
(8,8) \\
\end{array}$ & $\begin{array}{c}4 \\
(23,5) \\
\end{array}$ & $\begin{array}{c}0 \\
(0,0) \\
\end{array}$ & $\begin{array}{c}0 \\
(0,0) \\
\end{array}$ & \multirow{2}{*}{0,217} \\
\hline $\begin{array}{l}\text { Nadiren his kaybı durumu yaşayanlar ya da } \\
\text { hiç yaşamayanlar }\end{array}$ & $\begin{array}{c}21 \\
(87,5)\end{array}$ & $\begin{array}{c}83 \\
(91,2)\end{array}$ & $\begin{array}{c}13 \\
(76,5)\end{array}$ & $\begin{array}{c}14 \\
(100,0)\end{array}$ & $\begin{array}{c}4 \\
(100,0)\end{array}$ & \\
\hline
\end{tabular}

mamızda ortalama hastalık süresinin $9,4 \pm 6,9$ yıl gibi uzun bir süre olması da tedavi yöntemi üzerine etkili olabilir.

Çilingiroğlu'nun İstanbul ilinde yer alan iki özel hastanede diyabet polikliniğine başvuran ve hastanede tedavi gören 74 hasta üzerinde yapmış olduğu çalışmada hastaların \%43,2'sinde diyabetik nöropati, \%44,6'sında diyabetik nefropati, \%59,5'inde diyabetik retinopati, $\% 37,8^{\prime}$ inde diyabetik kardiyovasküler hastalık görülmüş olup, $\% 90,5$ 'inde diyabetik komaya rastlanmıştır. Sümerli’nin de Kayseri'de 30 diyabetli hastanın kişisel özellikleri ve tadavi sonuçlarını değerlendirmek için yapmıș olduğu araștırmasında hastaların \%26,66'sı retinopati, \%30'u nöropati, \%6,66'sı nefro- pati, \%16,66’sı kardiyovasküler hastalık, \%76,63’ü diyabetik koma gibi komplikasyonlarla sıkça karşılaştıkları belirtmiştir $(9,10)$. Araştırmamızda gönüllülerin 42 'sinde $(\% 28,0)$ diyabetik nöropati bulunurken, 23 'ünde (\%15,3) diyabetik nefropati, 20 'sinde $(\% 13,3)$ diyabetik retinopati, 15 'inde $(\% 10,0)$ diyabetik kardiyovasküler hastalık ve 143'ünde $(\% 95,3)$ diyabetik koma yaşanmış olduğu bulunmuştur. Üç çalışma arasında diyabetik koma yaşama durumu benzerlik göstermektedir ve en sık rastlanan komplikasyondur. Yine bizim çalışmamızda hastaların ikinci sıklıkla diyabetik nöropati yaşadıkları görülmüştür. Nöropati diyabetin uzun yıllar sonra, özellikle kontrolsüz seyrettiğinde sinir siste- 
minde olușturduğu hasardır. Hastalar fiziksel ve kimyasal travmaları fark edemezler. Nöropati sonucu ortaya çıan terleme azalması deri kuruluğuna ve deride çatlamalara neden olarak ayakta ülser gelişmesini kolaylaştırmaktadır.

Bölükbaş ve ark.nın Ordu Devlet Hastanesi Dahiliye Kliniği'nde yatan 105 DM'li hasta üzerinde yapmış oldukları çalışmada hastaların \%57,2'sinin diyabet hastalığında ayak bakımının önemli olduğunu düşündüğünü tespit etmişlerdir (8). Bizim çalışmamızda da hastaların 75'i $(\% 50,0)$ diyabet hastalığında ayak bakımının önemli olduğunu kesinlikle doğrulamaktadır. $\mathrm{Bu}$ araştırmanın sonuçları bizim çalışmamızla paralellik göstermektedir. Bölükbaş ve ark.nın yapmış oldukları çalışmada hastaların \%41,7'sinin ayak bakımı konusunda bilgiyi bir sağlık çalışanından almış olduklarını tespit etmişlerdir. Bizim çalışmamızda da hastaların \%45,3'ünün ayak bakımı konusunda bilgi aldığı ve bu bilgiyi \%73,5'inin sağlık personelinden aldıkları bulunmuştur. Hastaların \%50'sinin diyabet hastalığında ayak bakımının önemli olduğunu düşündüğünü belirtmelerine rağmen \%54,7'sinin bu konu hakkında eğitim almamış olmalarıda hasta eğitimine gerekli önemin verilmediğini göstermektedir. Yine alınan bilginin büyük çoğunluğunun sağlık çalışanından alınmış olması hastaların güvenilir bilgiye ulaştığını göstermektedir.

Bölükbaş ve ark.nın yapmış oldukları çalışmada hastaların \%52,3'ünün ayaklarını düzenli olarak yıkadığı, \%37,9'unun kuruladığı, \%9,8'inin ayak bakımı için özel kremler kullandığı, \%63,8’inin tırnaklarını düz kestiği, \%71,42 ünün pamuklu çorap ve $\% 80,0$ 'inin ise düz topuksuz ayakkabı giymeyi tercih ettiği bulunmuştur. Yine Güner'in yapmış olduğu bir çalışmasında hastaların \%27,8'inin ayak bakımı için krem kullandıkları tespit edilmiştir. Aypak ve ark. nın Dışkapı Yıldırım Beyazıt Eğitim ve Araştırma Hastanesi Aile Hekimliği Polikliniklerinde 200 DM hastası üzerinde yapmış oldukları başka bir çalışmada da hastaların $\% 63,0$ 'ünün tırnaklarını düz kestikleri ve $\% 69,5$ 'inin her gün ayak muayenesi yaptıkları bulunmuştur $(8,11,12)$. Araştırmaya katılan gönüllülerin 43 'ünün $(\% 28,7)$ her gün düzenli olarak ayaklarını yıkadığı, 32'sinin $(\% 21,3)$ her gün ayaklarını kuruladığı, 116’sının $(\% 77,3)$ hiç ayak bakım kremi kullanmadığı ve yine gönüllülerin 46 'sının $(\% 30,7)$ hiç ayak muayenesi yapmadığı bulunmuştur. Hastaların ayak bakım konusundaki davranışları da yeterli değildir. Bu davranış değişikliklerinin oluşturulması gerekmektedir. Yine bu çalışmada araştırmaya katılanların 58'inin $(\% 38,7)$ ayak tırnaklarını yuvarlak-oval şekilde kestiği, 85 'inin $(\% 56,7)$ pamuklu çorap kullandığı, 114'ünün (\%76) topuksuz ayakkab1 giymeyi tercih ettiği bulunmuştur. Diyabette ayak bakımı ile ilgili tırnakların düz kesilmesi, yüksek topuklu ayakkabı giymekten kaçınılması, pamuklu çoraplar giyil- mesi önerilmektedir (13). Bizim çalışmamızda hastaların çorap ve ayakkabı seçimi ile ilgili genel olarak doğru davranışları sergilediği, doğru tırnak kesme yöntemini kullanmada ise uygun davranış sergilemediği tespit edilmiștir. Ayrıca hastaların 89'unun $(\% 59,3)$ evde terlik giymeye hiç dikkat etmediği, 83'ünün $(\% 55,3)$ ayakkabılarını giymeden önce içini hiçbir zaman kontrol etmedikleri bulunmuștur. Bu da hastaların travma yaşama olasılıklarının yüksek olduğunu göstermektedir.

Yapılan çalışmalarda diyabet hastalarında ayak ile ilgili şikayetlerden en sık çatlak, yanma ve yaraların (enfeksiyonlar) görüldüğü anlaşılmaktadır $(8,6,14)$. Araştırmamızda hastaların ayaklarıyla ilgili en çok yanma hissi $(\% 48,7)$, enfeksiyon $(\% 46,0)$ ve çatlak-kuruluk $(\% 36,0)$ şikayetlerinin yaşandığı görülmüştür. Hastaların 117'sinin $(\% 78,0)$ ayakla ilgili bir sorun yaşadıklarında sağlık kuruluşuna başvurdukları bulunmuştur. Hastaların ayaklarıyla ilgili bir sorun yaşadıklarında \%78'inin sağlık kuruluşuna gitme davranışları olumlu yaklaşımların gelişebileceğini düşündürebilir.

Diyabetik ayakta hastaların ayak bakımı ile ilgili bilinç durumu ayak problemlerinin çözümsüz bir hâle gelmeden önlenmesi açısından çok önemlidir. Ancak eğitim tek başına sorunun çözümünde sınırlı etkiye sahiptir. Araştırma grubumuzda hastaların ayak bakımı konusunda bilgi alma durumlarına göre ayakta enfeksiyon yaşama, nasırlaşma, bül oluşumu, çatlak-kuruluk durumu, ülserasyon gelişimi, yanma, karıncalanma, soğukluk ve his kaybı yaşama durumları değişmemiştir. Bu sonuç diyabetik ayak ile ilgili şikayetlerin gelişiminde hastalığa ait özelliklerin, tedavi uyumunun, şeker regülasyonunun da çok önemli olduğunu düşündürmektedir. Hastalığın kliniği kişideki komplikasyonlarda belirleyici olabilir.

Bireylerin eğitim düzeyi ne kadar yüksek olursa hastalığa karşı tutumlarının ve tedaviye olan uyumlarının o kadar iyi olması beklenmektedir. Araştırmaya katılan hastaların eğitim durumları incelendiğinde okur- yazarlık durumları ile ayak bakımının önemi hakkındaki düşünceleri ve hastaların ayaklarını kurulamaya özen gösterme davranışları arasında anlamlı bir fark bulunmuştur. Lise mezunu olan hastaların \%92,9'unun ayak bakımının önemli olduğunu düşündügü ve \%71,4’ünün ayaklarını kurulamaya çok özen gösterdiği, okur-yazar olmayanların ise \%50,0'sinin ayak bakımının nadiren önemli olduğu ya da hiç önemli olmadığını düşündükleri ve $\% 79,2$ 'sinin ayaklarını nadiren kuruladıkları ya da kurulamaya hiç özen göstermedikleri bulunmuştur. Bunun yanında hastaların eğitim durumlarına göre ayaklarını her gün ılık su ile yıkama, kremleme, muayene etme ve evde yürürken terlik kullanmaya özen gösterme durumları farklılık göstermemiştir. Sonuç olarak hastaların 
eğitim düzeylerinin yüksek olmasına rağmen ayak bakım davranışlarında bireylerden istenilen sonuç elde edilememiştir. Hastaların eğitim durumlarına göre ayakkabılarını giymeden önce ayakkabının içini kontrol etme davranışları arasında da anlamlı bir fark bulunmuştur. Üniversite/ Yükseklisans mezunu hastaların \%75,0'inin ayakkabılarını giymeden önce ayakkabının içini sıklıkla kontrol ederken, okur-yazar olmayanların \%70,8'inin nadiren kontrol ettikleri ya da hiç kontrol etmedikleri bulunmuştur. Hastaların eğitim durumlarına göre ayaklarıyla ilgili enfeksiyon, nasırlaşma, bül, yanma durumu, karıncalanma ve his kaybı yaşama durumları arasında anlamlı bir fark bulunmamış olup, hastaların çatlak- kuruluk, ülserasyon ve soğukluk durumu yaşamaları arasında anlamlı bir fark bulunmuştur. Okur yazarlık seviyesi arttıkça çatlak- kuruluk, ülserasyon ve soğukluk durumu yaşama durumlarında azalma görülmüştür.

Sonuçta başarılı bir ayak bakımı ve ayak sağlığında sorunlar yaşanmaması için başta ayak yıkama, kurulama, olası çatlaklara sebebiyet vermemesi açısından kullanılan ayak bakım kremi kullanma gibi temel bakım ilkelerini uygulamaları ve yaşanabilecek komplikasyonlar açısından erken tanılama nedenli kendi kendine ayak muayenesi yapabilmeleri ve ayak muayene takiplerini hastanın kendi kendine düzenli yapabilmesi ve dolayısıyla hasta eğitimi çok önemli yer tutmaktadır. Ayak bakımı konusunda bilgi alma durumlarına göre hastaların \%94,1'i sıklıkla önemli olduğunu düşündüğü ve bu bilgi alan hastaların \%69,1'inin her gün ılık su ile ayaklarını yıkadığı, \% 57,4'ünün ayaklarını kuruladığı bulunmuş olup ayak bakım davranışları ile bilgi alma durumları arasında anlamlı fark bulunmuştur. Lise mezunu hastaların \%92,9'unun, üniversite/yükseklisans mezunu hastaların \%75,0'inin, okur-yazar olanların ise \%50,0'sinin sıklıkla ayak bakımının önemli olduğunu düşündügü görülmüştür. Hastaların eğitim durumlarına göre ayak bak1mının önemli olduğunu düşünmeleri arasında anlamlı bir fark bulunmuştur. Lise ve üniversite/yükseklisans mezunu olanların \%100,0'ünün nadiren ülserasyon durumu yaşadığı ya da hiç yaşamadığı, ortaokul mezunu olanların ise \%17,6'sının sıklıkla ülserasyon durumu yaşadıkları bulunmuştur. Hastaların eğitim durumlarına göre ülserasyon yaşama durumları arasında da anlamlı bir fark bulunmuştur. Sağlık çalışanlarının her kontrolde düzenli ayak muayenesi yapmaları ve ayak bakımına ilişkin hastaya bir form vermeleri ve bu form üzerinde işaretleme yapmanın önemini belirtmeleri gerekmektedir. Diyabetik hastalar için koruyucu ayak bakımı uygulamalarını içeren eğitim programlarının geliştirilmesi gerekmektedir. Hazırlanan eğitim programlarının eğitim ilkelerine uygun olarak hazırlanmasına ve sürekli olmasına dikkat edilmelidir. Her düzeyde ayak bakımı ilkelerine uyularak diyabete bağlı ayak komplikasyonlarını (basınç, yara, ülserasyon, amputasyon) önlemek yoluyla hastaların yaşam kalitelerinin yükseltilmesinin amaçlanması önerilebilir. Diyabetin sık görülen komplikasyonlarından olan diyabetik ayak oluşma riskini azaltabilmek için hastaları bu anlamda takip eden, değerlendiren ve olumlu davranıș değișikliklerinin oluşturulabilmesi için eğiten, koruyucu hekimlik felsefesinin önemsendiği merkezlere ihtiyaç vardır.

\section{Teşekkür}

Bu çalışma Özden Kalaycı'nın T.C.Bülent Ecevit Üniversitesi, Sağlık Bilimleri Enstitüsü, Halk Sağlı̆̆ı Anabilim Dalı Yüksek Lisans Tezinden üretilmiștir. Ayrıca IV. Zonguldak Endokrin Günleri, Ulusal Endokrin Hastalıklara Multidisipliner Güncel Yaklaşım Kongresi'nde Sözlü Bildiri (IV. Zonguldak Endokrin Günleri, Ulusal - Endokrin Hastalıklara Multidisipliner Güncel Yaklaşım Kongresi; Oturumlar ve Sunumların Özetleri. Türk Diyab Obez 2019;3:200-201.) olarak sunulmuştur. Yazarlar, Zonguldak Bülent Ecevit Üniversitesi Halk Sağlığı Anabilim Dalı Öğretim Üyelerine, Zonguldak Bülent Ecevit Üniversitesi Tip Fakültesi Endokrinoloji ve Metabolizma Hastalıkları Bilim Dalı Öğretim Üyeleri ile çalışanlarına teşekkür ederler.

\section{Etik Kurul Onayı}

Araștırma, Zonguldak Bülent Ecevit Üniversitesi Tıp Fakültesi Klinik Araştırmalar Etik Kurulu'ndan alınan 26.05.2015 tarih ve 2015/03 nolu etik kurul oluru sonrası gerçekleştirilmiştir.

Çıkar Çatışması

Yazarların bu araştırma ve makale için herhangi bir çıkar çatışmasi yoktur.

Finansal Destek

$\mathrm{Bu}$ araştırma için mali destek alınmamıştır.

Yazarların Makaleye Katkı Beyanı

Fikir ve tasarım; Özden Kalaycı, Bilgehan Açıgöz, Taner Bayraktaroğlu, Literatür tarama ve veri toplama; Özden Kalaycı ve Bilgehan Açıkgöz, Yorum ve Eleștirel Yaklaşım; Özden Kalaycı, Bilgehan Açıkgöz, Taner Bayraktaroğlu, Ferruh Niyazi Ayoğlu, Yazım: Özden Kalaycı, Bilgehan Açıkgöz, Sorumlu ve İletişim Yazarı; Özden Kalaycı.

Hakem Değerlendirmesi

Hakemlerin değerlendirmeleri ve önerileri sonrası yayınlanmaya kabul edilmiştir.

\section{KAYNAKLAR}

1. Türkiye Endokrinoloji ve Metabolizma Derneği Diabetes Mellitus ve Komplikasyonlarının Tanı, Tedavi ve İzlem Kılavuzu-2020 14. Baskı (Çevrimiçi Yayın): 25 Haziran 2020 (Güncellenmiş Baskı). (Erişim Tarihi: 01.07.2020, http://temd. org.tr/admin/uploads/tbl_kilavuz/20200625154506-2020tbl_ kilavuz86bf012d90.pdf.). 
2. Işık C, Sarman H, Şahin, AA, Karğı E, Sarman Z, Erkuran MK, Boyraz İ, Koç B. Diyabetes mellitüs ve periferik organ tutulumu: Güncel tedavi seçenekleri. JCEI. 2014;5(2):329-335.

3. T.C. Sağlık Bakanlığı Temel Sağlık Hizmetleri Genel Müdürlüğü, (2011-2014), Türkiye Diyabet Önleme ve Kontrol Programı Eylem Planı. (http://www.saglik.gov.tr/HM/ dosya/1-71375/h/turkiye-diyabet-onleme-ve-/kontrol-p\%20 rogrami.pdf: 29.11.2015).

4. Pan X-R, Li G-W, Hu Y-H, et al. Effects of diet and exercise in preventing NIDDM in people with impaired glucose tolerance. The da qing IGT and diabetes study. Diabetes Care. 1997;20(4):537-544

5. Diabetes Prevention Program Research Group. Reduction in the incidence of type 2 diabetes with lifestyle intervention or metformin. N Engl J Med. 2002;346:393-403.

6. Batkın D, Çetinkaya F. Diabetes mellitus hastalarının ayak bakımı ve diyabetik ayak hakkındaki bilgi, tutum ve davranışları. Sağlık Bilimleri Dergisi. 2005;14(1):6-12.

7. Çürüksulu H. Diyabetik ayak komplikasyonu bulunan ve bulunmayan DM'li hastalarda serum prokalsitonin, interlökin-6 ve hs-CRP düzeyleri. Uzmanlık Tezi, İstanbul, 2005.

8. Bölükbaş N, Paydaş M, Bostan Ö. Diyabetli hastaların ayak bakımı ile ilgili davranışlarının ve mevcut ayak durumlarının saptanması. Fırat Sağlık Hizmetleri Dergisi. 2006; 2(1): 82-91.
9. Sümerli K. Diyabet tedavisi gören hastaların hastalık ve tedavileri hakkındaki bilgi düzeylerinin belirlenmesi. Eczacılık Fakültesi Bitirme Ödevi. Kayseri, Mayıs 2012.

10. Çilingiroğlu EN. Diyabetli hastalarda insülin uygulama özelliklerinin değerlendirilmesi. İstanbul Bilim Üniversitesi Sağlık Bilimleri Enstitüsü Hemşirelik Yüksek Lisans Tezi. İstanbul, 2012

11. Güner A. Diyabetik hastaların diyabetik ayak ile ilgili bilgi ve tutumlarının irdelenmesi ve HbAlc'nin diyabetik ayal ile ilişkisi. T.C. Sağlık Bakanlığı Taksim Eğitim ve Araştırma Hastanesi Aile Hekimliği Uzmanlık Tezi. İstanbul, 2005.

12. Aypak C, Koç A, Yıkılkan H, Görpelioğlu S. Diyabet ayak bakımı: Aile hekimliği polikliniğine başvuran hastalar tarafindan bildirilen uygulama durumu. Cumhuriyet Tip Derg. 2012;34:423-428.

13. Giritli G. 'Diyabetli Hastalarda Ayak Bakımının Önemi'. (http://www.istanbulsaglik.gov.tr/w/sb/per/belge/diyabetik_ ayak.pdf: 03.10.2015).

14. Fadıloğlu Ç, Yeşilbalkan ÖU, Yıldırım YK, Özer S, Tokem Y. Yaşlı diyabetik hastalarda ayak sorunlarının saptanması. Ege Üniv. Hemşirelik Yüksek Okulu Dergisi. 2006;22(2):161-170. 